\title{
The 2007 Leegin Decision on Resale Price Maintenance and Its Implications for Firms' Distribution Strategies
}

Joseph M. Jadlow

Oklahoma State University • Stillwater, OK

\begin{abstract}
With its Leegin decision in June 2007, the U.S. Supreme Court adopted a much more permissive judicial attitude toward businesses' use of vertical price restraints than had been the case for almost a century. In most instances, manufacturers will now be able to use minimum resale price maintenance when dealing with retailers without violating federal antitrust laws. This should increase the efficiency of product distribution. Some firms are unlikely to be able to take full advantage of these more efficient distribution methods, however, because the antitrust laws of some individual states are likely to conflict with the new federal rules.
\end{abstract}

\section{Introduction}

In late June 2007, the U.S. Supreme Court announced an antitrust decision that is likely to change the distribution methods that many businesses use to market their products. The case was Leegin Creative Leather Products v. PSKS (2007) and it reversed a court precedent that had stood for close to a century. With this recent decision, the Court adopted a much more permissive judicial treatment of resale price maintenance than had been the case before.

The purpose of this paper is to examine how Leegin alters the distribution methods that firms have at their disposal and to analyze the likely effects on the efficiency of the distribution process. The paper finishes by identifying some lingering antitrust concerns for business that temper the increased distribution flexibility and efficiency precipitated by Leegin.

\section{The Leegin Decision}

The U.S. Supreme Court had ruled in the Dr. Miles (1911) case that all resale price maintenance is per se illegal under Section 1 of the Sherman Act. Resale price maintenance (RPM) is when an upstream firm, such as a manufacturer, requires an independent downstream reseller, such as a retail dealer, to agree to restrictions on the price at which the dealer resells the firm's product. More specifically, minimum RPM is an agreement that the product will not be resold at a price below a specified 
level while maximum RPM is an agreement that the product will not be resold above a given price. The per se prohibition meant that RPM was automatically illegal, i.e. there were no justifications that the courts would consider in defense of a defendant who had employed it. Minimum RPM remained per se illegal under Dr. Miles until the 2007 Leegin decision. The rule of reason was adopted for maximum RPM in a 1997 Supreme Court opinion (State Oil Co. v. Khan); the reason for the latter is explained in a section below.

In late 2002, the manufacturer of Brighton brand products, Leegin Creative Leather Products, Inc., learned that an independent retailer in Lewisville, Texas was selling the entire line of Brighton products at prices 20 percent below those recommended by Leegin; in response, Leegin quit supplying the product label to the retailer and the retailer filed a law-suit against Leegin for per se illegal minimum RPM. On the last day of its 2006-2007 term, a 5-4 majority of the Supreme Court overruled the Dr. Miles precedent with its Leegin (2007) decision that held that all vertical price restraints are to be judged by the rule of reason, i.e. on a case-by-case basis that weighs the competitive benefits and costs in each instance.

\section{Business Reasons for Firms to Use Vertical Restraints}

It is frequently the case that the manufacturer of a differentiated product prefers its dealers to provide various services that will increase the demand for its product. For example, it might want stores to have trained sales personnel who are knowledgeable about its product, its advantages over other brands, warranty issues, the expected life of the product, and other product-specific information. It also may want retailers to carry certain types of store displays for the product, maintain a given type of shopping-environment, maintain minimum inventory levels, provide various post-sale services, do local advertising, and have a reputation for selling high-quality products (Elzinga \& Mills, 2007; Ippolito, 1991; Marvel \& McCafferty, 1984). Such services are costly but the manufacturer may expect that if each of its retailers offers them, they will more than pay for themselves by increasing the overall demand for his product.

If it does not protect itself, however, the manufacturer may encounter the well-known "free rider" problem (Telser, 1960) as some of its retailers begin to cut back on services so as to reduce costs, discount their prices, and gain market share. The full-service retailers whose services helped create the expanded demand suffer the direct effects of the free riding as they lose sales to the discounters and eventually are forced to eliminate services themselves so that they can charge low enough 
prices to maintain their market shares. The net effect is the overall demand for the manufacturer's product falls and so do its profits. There are various possible ways that the manufacturer might try to solve the problem but, of course, in doing so it would want to be both efficient and lawful.

One possibility is that the manufacturer vertically integrates and sells the product at retail itself. The manufacturer could do this by acquiring retail stores through a series of mergers or it could build its own network of retail stores. If the manufacturer does vertically integrate, this solves the free rider problem because the producer gains direct control of the services that its retail outlets provide as well as the prices they charge. While in most instances it seems unlikely that a firm's decision to vertically integrate would be found to violate the antitrust laws, it is also true that vertical integration would not be cost-effective for most firms.

An alternative to vertical integration is to assign exclusive sales territories to the various retail stores with whom it deals and to make each dealer's provision of specified services a contractual requirement for continuing to have an exclusive territory. This provides an incentive for each dealer to offer the desired services because any additional sales prompted by the dealer's services are internalized with the dealer (rather than spilling over to free riders selling the same brand) since no other dealers are allowed to market the brand in the same geographic territory. The business practice of assigning exclusive sales territories to downstream dealers is a non-price vertical restriction that has been governed by the rule of reason since the Supreme Court's Continental T.V., Inc. v. GTE Sylvania Inc. (1977) decision and its use will rarely be found to be illegal; the main rationale given by the Court for its adoption of the rule of reason for such restraints was the free rider problem. A side-effect of assigning exclusive territories is that it gives the dealer increased market power and an incentive to raise the price it charges above the level that maximizes the profits of the manufacturer. The manufacturer can solve this doublemargin problem by using maximum RPM to force the dealer to charge a price no higher than what is optimum for the manufacturer (Blair \& Kaserman, 1985, pp. 342-347). Because the use of maximum RPM results in lower prices, higher outputs, and increased consumer welfare, the Supreme Court held in its Khan (1997) decision that it was adopting the rule of reason for evaluating this business practice, and it is unlikely that its use will ever be found to violate the antitrust laws.

The Leegin decision has made available another option for the upstream firm - the use of minimum RPM. By requiring downstream dealers to agree that they will not sell the product for less than a minimum price specified by the manufacturer, the manufacturer can attempt to attract good dealers to sell and promote its product 
brand by promising them sizable price-cost margins that will not be threatened by discounters. In its contracts with dealers, the manufacturer can make clear the nature and quality of the services that the dealers are expected to provide in retailing the product and, by its effective use of minimum RPM, the manufacturer can ensure that dealers' profit margins are large enough so that they can cover the costs of the desired services. If the manufacturer is a new firm with a new product or if it is an old firm that wants to enter a new market, its use of minimum RPM can be especially important in attracting strong dealers and in facilitating its overall success (Elzinga \& Mills, 2007, p. 7).

Prior to the Leegin decision, any firm that used minimum RPM and was the subject of a formal antitrust complaint was very likely to be found to have committed a per se violation of the Sherman Act except in some very special circumstances. The latter exceptions resulted from a series of Supreme Court decisions that identified a few roundabout ways for de facto RPM to be used without committing a per se violation. For example, the Court ruled in Colgate (1919) that an upstream firm could announce and then carry out a unilateral policy of refusing to sell to dealers who charged prices below its suggested retail prices - but there could be no haggling with dealers to get them to abide with the price floor. Then in General Electric (1926), the Court held that in a true consignment arrangement an upstream firm (principal) could determine the price at which a dealer (agent) sold the product because ownership remained with the upstream company until sale to the final consumer was completed. Later in Monsanto (1984) and in Business Electronics (1988), the Court issued rulings that made it very difficult for a plaintiff to prove per se illegal minimum RPM based mainly on evidence that the plaintiff had been terminated as a dealer after a competitor of the plaintiff complained about him to the manufacturer. The rule of reason was applied in all of these de facto RPM situations.

While the empirical evidence is limited, the above discussion suggests that before Leegin, the Dr. Miles precedent limited the distribution options of firms. For example, in situations where the use of minimum RPM would have been the cheapest way to get good full-service dealers and keep them, some manufacturers either had to forego this method entirely (so as to avoid being charged with per se illegal minimum RPM) or attempt to use one of the more costly and risky de facto RPM approaches such as the unilateral policy permitted by Colgate; other producers may have chosen to vertically integrate even when it was less efficient than the use of minimum RPM. In citing these perverse effects of the Dr. Miles per se rule, the Supreme Court concluded that the rule ". . . hinders competition and consumer wel- 
fare because manufacturers are forced . . . to choose second-best options to achieve sound business objectives" in distributing their products (Leegin, 2007, pp. 23 and 25 ). Thus, by permitting a wider range of distribution options than were previously available, the 2007 Court decision seems likely to increase the overall efficiency of product distribution in the economy.

\section{Caveat Venditor: "Let the Seller Beware"}

While Leegin has expanded the distribution options available to companies, there are some strong cautionary warnings for them to keep in mind. First, there continue to be instances where the use of minimum RPM may be found to violate federal antitrust law under the rule of reason (Denger $\&$ Lipton, 2007). For example, it is generally recognized that a dealer cartel or a manufacturer cartel could try to use minimum RPM as a method of preventing members of the cartel from cheating. Ordinarily manufacturers would have no incentive to facilitate the cartel efforts of dealers but if the impetus for the use of RPM appears to be from dealers or even from one dominant retailer, antitrust enforcement agencies are likely to scrutinize behavior carefully. Similarly, the Supreme Court has emphasized that if the adoption of RPM is widespread throughout an industry or if a dominant producer with market power introduces RPM, close scrutiny is likely (Leegin, 2007).

The second and most important concern, however, is the uncertainty about how the individual states will treat minimum RPM in the wake of Leegin. Notably, the attorneys general of thirty-seven states asked in an amici brief in Leegin that the per se rule of $\mathrm{Dr}$. Miles be kept. ${ }^{1}$ This does not mean that all these states will adopt a per se rule at the state-level since the views of state courts or legislatures may differ from those of the state attorneys general. But it does indicate that businesses should proceed with care. Two antitrust lawyers have attempted to anticipate the RPM policies of various states and they recommend that firms move cautiously in forming new RPM programs; they conclude that minimum RPM agreements would be "riskiest for businesses" in California, New York, and New Jersey (Wofford \& Limarzi, 2007, p. 7). Another legal expert has suggested that companies that had a Colgate-type unilateral pricing policy before Leegin may want to continue that policy and ones that never adopted such a policy because the "perceived risk was too great" may now want to consider adopting one because the risk has fallen somewhat because of Leegin (Lindsay, 2007, p. 36). 


\section{Summary and Conclusions}

The Supreme Court's recent decision to move to rule of reason treatment for all resale price maintenance has expanded the choice set of companies for distributing their products and, as described above, this should result in some lowering of firms' costs and increased efficiency in providing distribution services to consumers. The fact, however, that the Leegin decision only bears directly upon the enforcement of the federal antitrust laws, limits the scope of its benefits to firms and the economy. It is important that companies thinking of changing their distribution methods in response to Leegin should first consider state antitrust laws and policies toward minimum RPM that are relevant for their business. If a company wants to use minimum RPM but is uncertain about how it will be treated under state antitrust laws, the Colgate unilateral pricing policy may suit its purposes.

\section{Note}

1. The states are Alaska, Arkansas, Connecticut, Delaware, Florida, Hawaii, Idaho, Illinois, Iowa, Kansas, Kentucky, Louisiana, Maine, Maryland, Massachusetts, Michigan, Minnesota, Mississippi, Missouri, Montana, New York, Nevada, New Hampshire, New Jersey, New Mexico, North Carolina, Ohio, Oklahoma, Oregon, Pennsylvania, South Carolina, South Dakota, Utah, Vermont, Washington, West Virginia, and Wyoming. (Brief of States, 2007)

\section{References}

Bork, R. H. (1978). The antitrust paradox. New York: Basic Books.

Blair, R. D., \& Kaserman, D. L. (1985). Antitrust economics. Homewood, IL: Richard D. Irwin, Inc.

Brief of States as Amici Curiae Supporting Respondent, Leegin Creative Prods., Inc. v. PSKS, Inc., No. 06-480, WL 621851(127 S. Ct. 2705 2007).

Business Electronics Corp. v. Sharp Electronics Corp., 485 U.S. 717 (1988).

Continental T.V., Inc. v. GTE Sylvania Inc., 433 U.S. 36 (1977).

Denger, M. L., \& Lipton, J. (2007). The rule of reason and "Leegin policies": The Supreme Court's guidance. Antitrust, 22(1), 45-50.

Dr. Miles Medical Co. v. John D. Park \& Sons Co., 220 U.S. 373 (1911).

Elzinga, K. G., \& Mills, D. E. (2007). The economics of resale price maintenance. In W. D. Collins (Ed.), Issues in competition law and policy. American Bar Association. Retrieved September 26, 2007, from ssrn.com/abstract=926072. 
Hovenkamp, H. (2005). The antitrust enterprise. Cambridge, MA: Harvard University Press.

Ippolito, P. M. (1991). Resale price maintenance: Empirical evidence from litigation. Journal of Law and Economics, 34, 263-94.

Kleit, A. N. (1993). Efficiencies without economists: The early years of resale price maintenance. Southern Economic Journal, 59, 597-619.

Leegin Creative Leather Products v. PSKS, 551 U.S. (2007).

Lindsay, M. A. (2007). Resale price maintenance and the world after Leegin. Antitrust, 22(1), 32-40.

Marvel, H. P., \& McCafferty, S. (1984). Resale price maintenance and quality certification. Rand Journal of Economics, 15, 346-59.

Monsanto Co. v. Spray-Rite Service Corp., 465 U.S. 752 (1984).

Scherer, F. M., \& Ross, D. (1990). Industrial market structure and economic performance (3rd ed.) Boston: Houghton-Mifflin Co.

State Oil Co. v. Khan, 522 U.S. 3 (1997).

Telser, L. G. (1960). Why should manufacturers want Fair Trade? Journal of Law and Economics, 3, 86-105.

United States v. Colgate \& Co., 250 U.S. 300 (1919).

United States v. General Electric Co., 272 U.S. 476 (1926).

Wofford, Jr., M.R., \& Limarzi, K. C. (2007). The reach of Leegin: Will the states resuscitate Dr. Miles? The Antitrust Source. American Bar Association. Retrieved October 19, 2007, from www. antitrustsource.com.

\section{Biographical Sketch of Author}

Joseph M. Jadlow is Professor of Economics at Oklahoma State University, Stillwater. He received his Ph.D. from the University of Virginia. His research interests include antitrust economics, rent seeking behavior, public choice, history of economic thought, and law \& economics. He has published in the Journal of Finance, Public Choice, Bell Journal of Economics, Antitrust Law \& Economics Review, and Managerial and Decision Economics, among others. 
